\title{
The Brooklyn Navy Yard: the heart of the Union Anaconda
}

\section{William Whyte}

Un des plus grands obstacles rencontrés par l'Union pendant la Guerre Civile a été d'équipper et de maintenir une flotte pour effectuer le blocus de toute la côte sud proclamé par le président Abraham Lincoln lors du déclenchement du conflit. Le chantier naval de Brooklyn était essentiel à cet effort. Il incarne l'évolution des opérations navales des États-Unis qui ont eu lieu pendant la guerre civile, et la myriade de problèmes qui ont dî être surmontés. Le présent document se concentre sur les opérations logistiques vitales qui ont permis à l'Union d'établir rapidement un blocus, et plus important encore, le maintenir à flot. Près de la moitié des navires civils utilisés par la marine et l'armée pour ce service pendant la guerre ont été préparés dans ce chantier, qui a également fourni des services indispensables tels que la réparation et la construction navale, le recrutement et la formation navale, l'entreposage et la distribution d'armements, d'équipement et de fournitures, et les soins médicaux.

"It is beyond question to be the great naval depot of the nation, and therefore the country will not stop to count the cost of making the necessary improvements to answer the important ends the service requires."

Commodore Joseph Smith - chief of the Bureau of Yards and Docks, 1863, in reference to the Brooklyn Navy Yard. ${ }^{1}$

A large crowd gathered at the Continental Iron Works ship yard in Greenpoint, Brooklyn, to watch a strange new iron vessel float onto the East River on 30 January 1862. The ironclad Monitor, assembled in four months, made its way down river to the Brooklyn Navy Yard where it was provisioned, underwent sea trials, and commissioned. It was towed out of the yard on 6 March 1862, and sailed south to Hampton Roads, Virginia. Three days later, the USS Monitor engaged the CSS Virginia in the epic, but inconclusive, battle of ironclads. $^{2}$ The fact that one of the most storied vessels of the U.S. Navy was

$1 \quad$ U.S. Senate, Annual Report of the Secretary of the Navy, 38th Cong., 1st Sess., 7 December 1863, 613. (Hereafter cited as SECNAV Report, 38th Cong., 1st Sess., 7 December 1863, 613). Smith made this comment to justify the large budget being proposed for New York as opposed to the other naval yards.

2 Ari Hoogenboom, Gustavus Vasa Fox of the Union Navy (Baltimore: Johns Hopkins

The Northern Mariner/le marin du nord, XXII No. 4, (October 2012), 393-407 
commissioned at the Brooklyn Navy Yard was not a coincidence. The yard was imperative to Union naval operations during the Civil War: fifteen ships were constructed there, and at least half of the 418 vessels purchased during the conflict were acquired in New York with a majority of them being provisioned at the yard itself. ${ }^{3}$ The facility also served as a ship repair terminal, naval receiving station, ordnance and supply depot, and a naval hospital. The New York yard was the most important Union naval station. It epitomized the evolution of U.S. naval operations that occurred during the Civil War, and the myriad of problems that went along with it. This paper does not intend to render the services of the other navy yards and stations irrelevant, for each played an important role, but a focus on the New York navy yard provides an excellent case study to exhibit its significant contribution to the remarkable feats achieved by the Union Civil War navy.

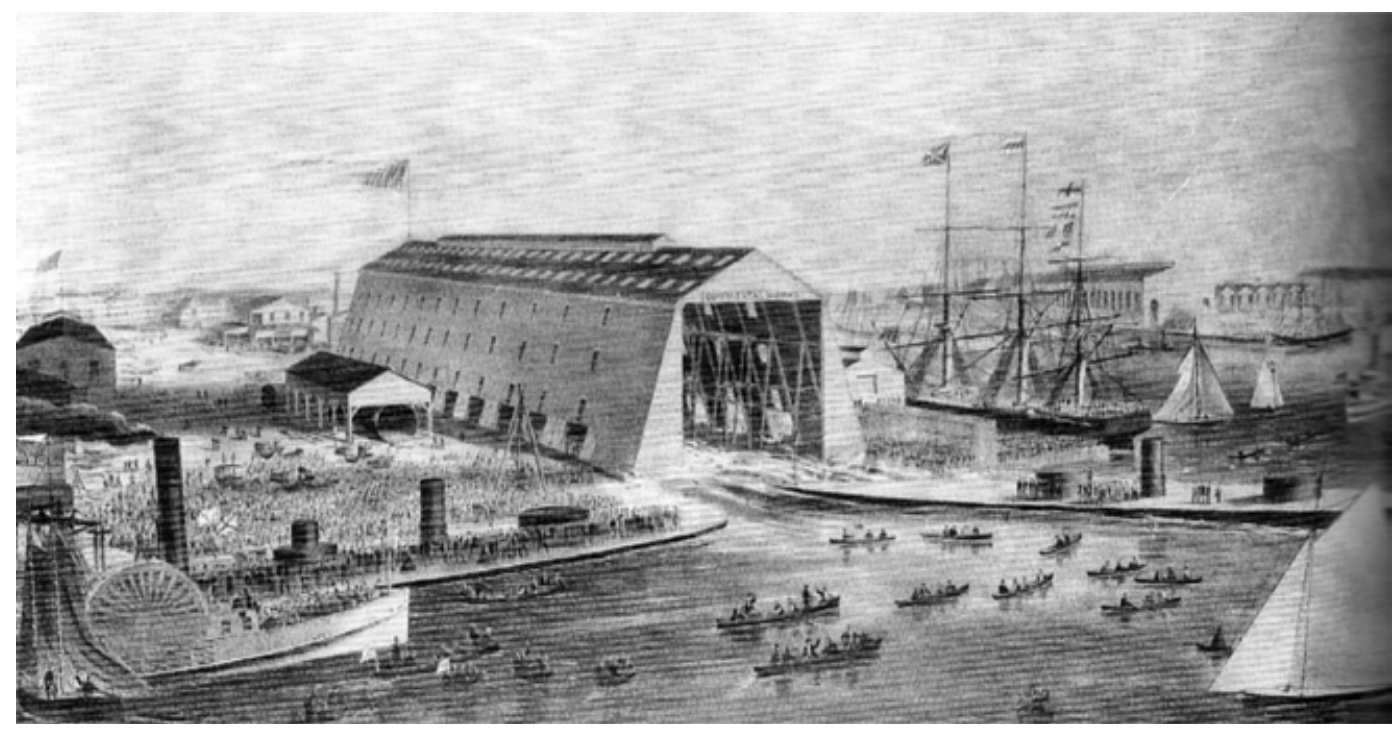

Illustration 1 - The Continental Ironworks launched seven ironclads during the war, including the USS Monitor.

\section{The Yard}

Shipbuilders of the early American Republic recognized the favorable terrain of the Brooklyn-Manhattan littoral. The yard was officially established on 23 February

University, 2008), 111; For the orders of Lieutenant John L. Worden, commander of the Monitor, to proceed to Hampton Roads see: U.S., Navy Department, Official Records of the Union and Confederate Navies in the War of the Rebellion, Series I, Vol. 6, 679. (Hereafter cited as ORN, I, 6:679).

3 For ships constructed in yard, see: "The New York Navy Yard," Presented at the Annual Meeting of The Society of Naval Architects and Marine Engineers, No. H-5 (New York, 1943); For vessels acquired see: Donald Canney, Lincoln's Navy: The Ships, Men and Organization, 1861-65 (Annapolis: Naval Institute Press, 1998),44; The exact numbers vary, Canney argues that 190 of 380 vessels purchased were handled by New York. The author's numbers compiled from the ORN indicate more. All sources agree that New York handled at least half. 
1801 under the direction of Secretary of the Navy Benjamin Stoddard. The frigate USS Adams was constructed at the site in 1798. Located east of Manhattan Island, the Brooklyn Navy Yard was situated along a crescent-shaped inlet, one mile wide and a half mile long, called Wallabout Bay, which provided sanctuary from the turbulent East River, while giving easy access to New York City and its bustling harbor. The coast around the bay was part of George Washington's defenses during the Battle of Long Island, but Wallabout is most often remembered as the mooring place of the notorious British prison hulks, where thousands of continental captives perished during the American Revolution. The first commandant, Lieutenant Jonathan Thorn, took charge on 1 June 1806, and began constructing permanent facilities. ${ }^{4}$ Fifty years later, a modern industrial plant emerged.

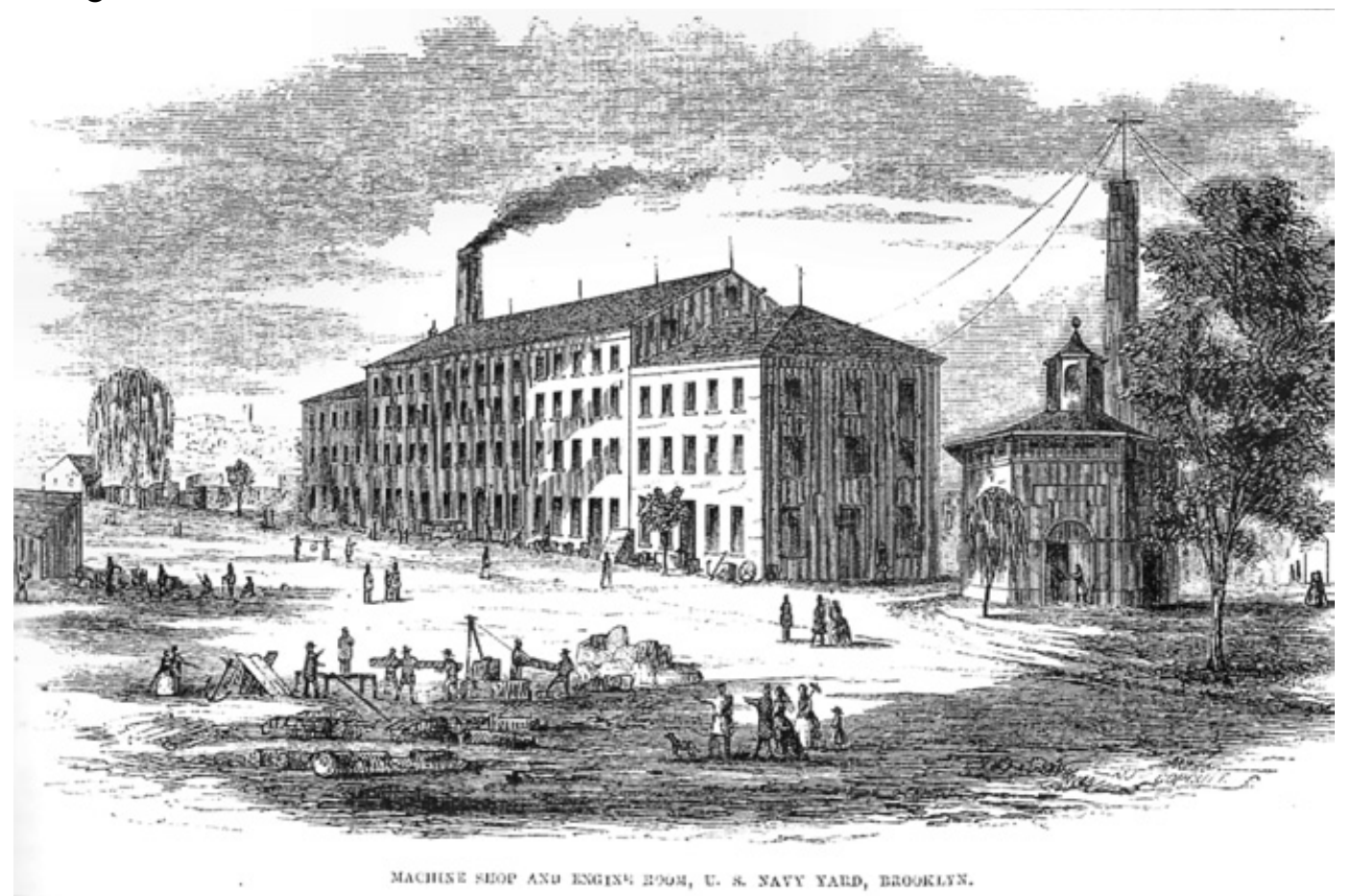

Illustration 2 - Machine Shop at Brooklyn Navy Yard

Newspaper editor Frank Leslie characterized the antebellum Brooklyn Navy Yard as one of the "lions" of New York. A glimpse at the yard in 1857 reveals why it was indispensable to the Union Navy. Leslie described the scene from the Naval Marine Hospital looking out over the bay where the receiving ship North Carolina was berthed (receiving ships were older vessels permanently moored at the various yards, and used for housing and training new recruits) along with three other naval vessels. A soon to be obsolete fleet of sail frigates floated quietly in the bay. Past the armada, a convoy of civilian merchant ships unloaded supplies. Leslie described a massing on the shore of

4 James H. West, A Short History of the Brooklyn Navy Yard (New York: New York Naval Shipyard, 1941), 1,6,13-14,19-20. 
iron and brick buildings with smoke billowing out through large chimneys. It was an industrialized town,with a 9,000 square foot iron shed for gun carriages, a three-winged smithery containing a labyrinth of underground piping for ventilation, a 12,000 square foot boiler shop, plus a foundry, oakum warehouse for sealing hulls, carpenter and plumbing shops, and an armory.

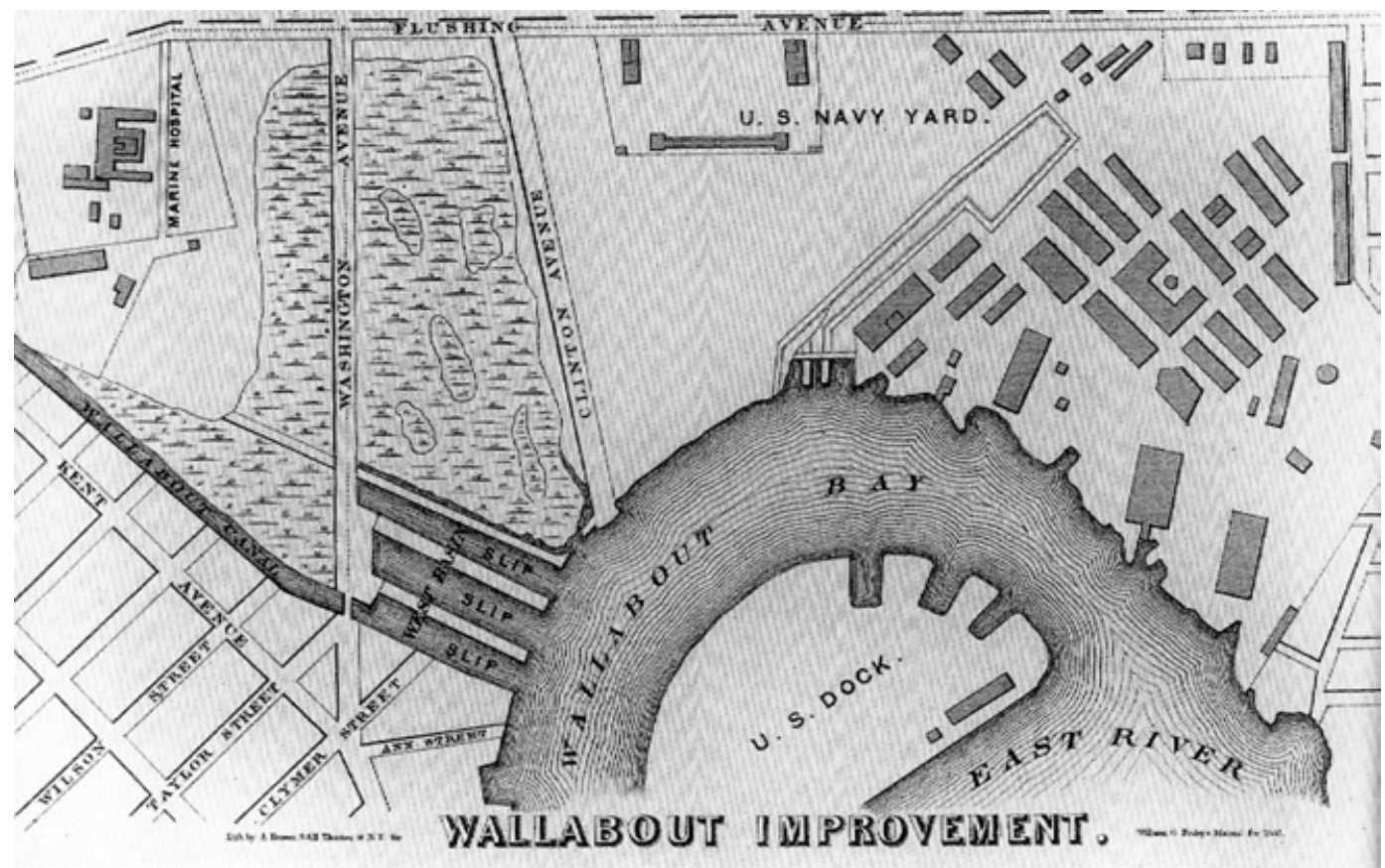

Illustration 3 - Layout of Brooklyn Navy Yard

In an era when public parks were scarce, many New Yorkers liked to stroll the navy yard's grounds. One of the most popular destinations for the public was the museum and library at the Naval Lyceum. The lyceum was established in 1833, and served as headquarters for a society of naval and marine officers; members promoted the establishment of a naval academy and were strong advocates for a steam navy. The lyceum's library was renowned throughout the country for its collection of nautical books. Some historians have pointed to this organization as the forerunner to the U.S. Naval Institute. ${ }^{5}$ Certainly the library enhanced the capability and prestige of the New York navy yard.

Along with its extensive plant on shore, the yard boasted excellent berthing and docking facilities for ship building and repair. There were no piers, but Wallabout Bay

$5 \quad$ Frank Leslie, "A Visit to the Brooklyn Navy Yard," Frank Leslie's Illustrated Newspaper, 14 February 1857; Frank Leslie, "Second Visit to the U.S. Navy Yard, Opposite New York City" Frank Leslie's Illustrated Newspaper, 1 August 1857; Many of the library's collections were donated to the U.S. Naval Academy (founded in 1845) after 1888. West, A Short History of the Brooklyn Navy Yard, 79. See also: Canney, Lincoln's Navy, 43-44. 


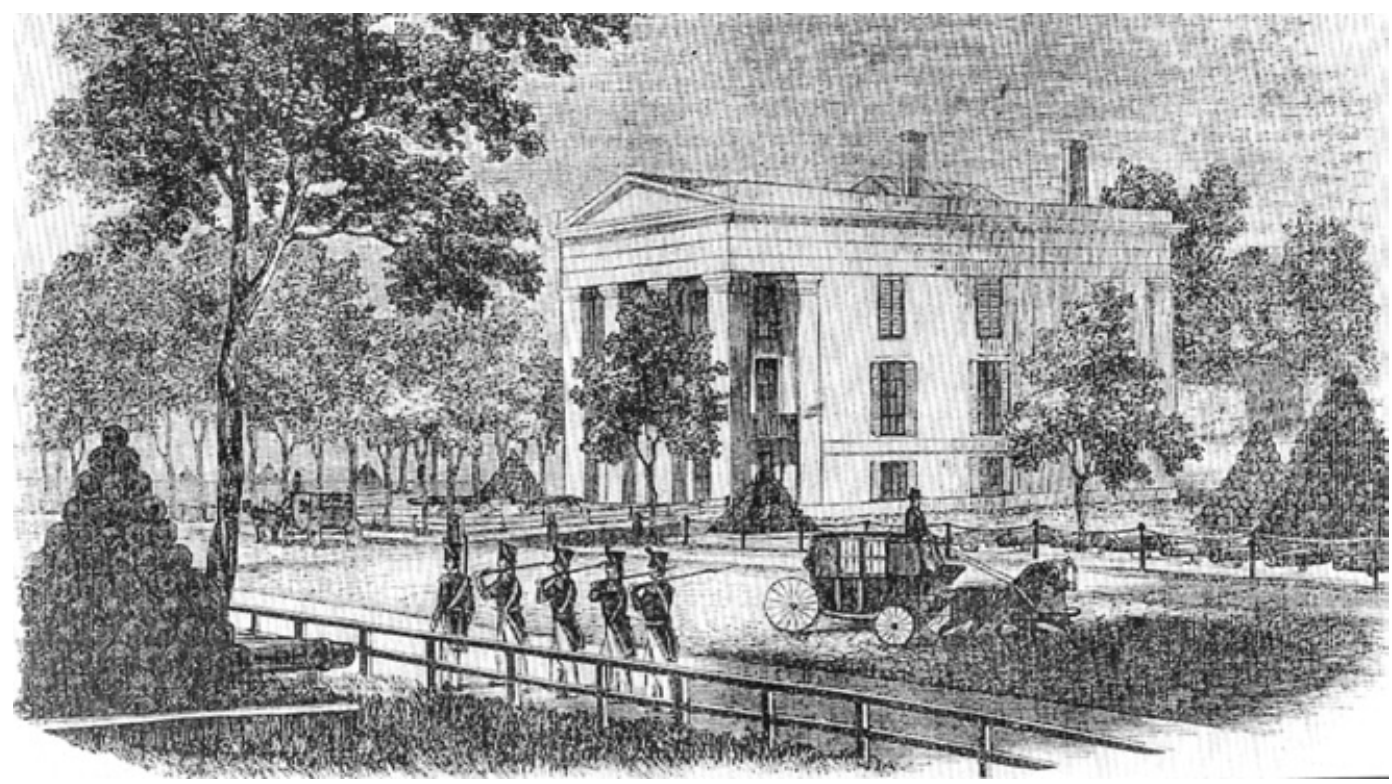

Illustration 4 - The Naval Lyceum at the Brooklyn Navy Yard

provided almost a mile and a half of water front for vessels to moor alongside. An artificial islet called Cob Dock, created over the years by the dumping of cobblestone ballast by incoming ships, provided more berths. Cob Dock was expanded during the war, and the perimeter cribbed with wood pilings to accommodate the increased ship traffic. Also on the waterfront were two large warehouses to support shipbuilding and repair, a floating dock, and a launching slip, but the most impressive feature was Dry Dock \# 1 Completed in 1851, its construction had taken ten years, required over 80,000 tons of stone and cost nearly $\$ 2,000,000$. It could dock a vessel in less than three hours, compared to ten hours for docks at other yards. The formidable structure still exists today. ${ }^{6}$

\section{Union Naval Strategy and Facilities}

Lieutenant General Winfield Scott, the U.S. Army's chief of staff at the beginning of the Civil War, articulated the broad Union war plan by suggesting that the Southern states could be subjugated by "enveloping them all (nearly) at once by a cordon of posts on the Mississippi to its mouth from its junction with the Ohio, and by blockading ships of war on the sea-board." ${ }^{7}$ The Union press derogatorily labeled this strategy the Anaconda Plan. The Anaconda implied a slow strangulation of the Southern economy by

6 Canney, Lincoln's Navy, 43; West, A Short History of the Brooklyn Navy Yard, 66-67; Rebecca Paulding Meade, Life of Hiram Paulding; Rear-Admiral, USN (1910; repr., Memphis: General Books, 2010), 102-3; William Thiesen, Industrializing American Shipbuilding (Gainesville: University of Florida Press, 2006), 74.

7 U.S., War Department, The War of the Rebellion: A Compilation of the Official Records of the Union and Confederate Armies, series I, vol. 51, 338-39. (Hereafter cited as ORA, I, 51:338-39). 
sealing off the Mississippi River and the Southern deep-water ports. Many on both sides believed the conflict would be short-lived, and the press opined that this ponderous strategy that could bring effects only over a considerable span of time reflected the pessimism and caution of an aged senior officer. In fairness, Scott had offensive operations in mind as well because he realized the Northern population would not stand idly by waiting for the Confederacy to collapse from economic strangulation. ${ }^{8}$ A variation of this strategy ultimately sealed the fate of the Confederacy.

U.S. naval strategy developed in response to political considerations rather than military. One of the greatest challenges facing the Union Navy during the Civil War was procuring and maintaining ships for the blockade of the Confederate coast. On 19 April 1861, President Abraham Lincoln declared a naval blockade of the Southern ports in South Carolina, Georgia, Alabama, Florida, Mississippi, Louisiana and Texas. ${ }^{9}$ Lincoln, perhaps concerned over European intervention, declared a formal blockade rather than just closing the Southern harbors. In international law, a declaration of blockade required that authorities notify all craft of the port's closing, that foreign vessels had fifteen days to depart, and incoming vessels had to be warned of the blockade. More important, for the blockade to have standing in international law, it had to be "effective," that is the blockading power had to have sufficient warships on station to intercept vessels attempting to enter or leave the port. ${ }^{10}$

Politics aside, Lincoln's decision was a bold move considering the state of the U.S. Navy at that time. Many southern-born officers had resigned their commissions or were planning to resign. Other officers openly expressed hostility towards Lincoln's secretary of the navy, Gideon Welles. The country's antebellum political strife and scant military appropriations had left the eight operational navy yards antiquated and the fleet ill-prepared for the scale of naval operations that would be required during the Civil War.

In 1861, the U.S. Navy consisted of ninety vessels: forty-two in commission and another forty-eight laid up in ordinary or serving as receiving ships. Approximately 1,300 officers and 7,500 sailors crewed the fleet. Most of the commissioned ships were serving abroad, leaving a meager home squadron of twelve vessels, with 187 guns, and about 2,000 crew to defend the Union. By the end of the war, the United States boasted a navy second only to Great Britain with 671 ships, 6,700 officers, and over 51,000 enlisted personnel. ${ }^{11}$

This epic transformation would begin in the nation's Federal navy yards, driven by the enormous demands of the blockade. From the start, the yards were the spine of the vast logistical organization needed to mount and sustain the blockading forces. The six

8 Theodore Ropp, “Anacondas Anyone?” Military Affairs 27 (summer 1963): 72-74.

9 ORN, I, 5:620. The ports of Virginia and North Carolina were added to the blockade list on 1 May 1861.

10 Richard S. West Jr., Mr. Lincoln's Navy (New York: Longmans, Green, \& Co., 1957), 57-58.

11 Charles O. Paullin, Paullin's History of Naval Administration: 1775-1911 (Annapolis: U.S. Naval Institute, 1968), 268-69; Spencer Tucker, Blue and Gray Navies (Annapolis: Naval Institute Press, 2006), 30. 
original yards, founded at the turn of the nineteenth century, were: Norfolk, Virginia; Brooklyn, New York; Boston, Massachusetts; Portsmouth, New Hampshire; Washington D.C.; and Philadelphia, Pennsylvania. Two additional stations were established at Pensacola, Florida (1825) and Mare Island, San Francisco (1853). Wartime exigencies necessitated the creation of additional stations: Baltimore, Maryland; Port Royal, South Carolina; Beaufort, North Carolina; Key West, Florida; New Orleans, Louisiana; Memphis, Tennessee; and Cairo and Mound City, Illinois. Mare Island was too far removed from the theatres of operation to assist in the blockade, although it did support deep-water cruisers that hunted Confederate raiders. Boston and Portsmouth were excellent facilities for ship construction, but too far north for the quick turnaround that was required of blockade operations. Philadelphia and Washington D.C. were smaller yards; Philadelphia had icing problems in the winter, while the Washington Yard, a favorite of President Abraham Lincoln, specialized in ordnance, cables, and anchors. Pensacola was also small with limited repair capabilities and was in the hands of the Confederacy at the start of the war. ${ }^{12}$ The largest yard was Norfolk; its loss in April 1861 ensured that New York would be vital to the Union blockade.

The fall of Norfolk was a major setback for Union naval plans. A series of vacillating orders, an inept and ageing commander, Commodore Charles S. McCauley, combined with a staff of officers sympathetic to the southern cause led to the yard being taken nearly intact. Welles ordered Captain Hiram Paulding to relieve McCauley, but he arrived too late on 20 April 1861. Fleeing Unionists failed to completely destroy the formidable steam frigate USS Merrimack (soon to be converted by the Confederates into the ironclad CSS Virginia) or most of the machine shops. Nearly 2,000 cannon were seized - guns that would soon be pointed at the Union blockaders. ${ }^{13}$ The yard was not in Confederate hands for long. However, the secessionists did a thorough job in destroying it in May 1862 before they retreated during the Peninsula Campaign. Upon taking command, Union Captain John W. Livingston found only three machine shops salvageable and most of the channel filled with obstructions. The annual report to Congress by the secretary of the navy for that year did not even request appropriations for the yard and most of the recoverable machinery was dispersed to other facilities. By the end of 1863, the yard was still only capable of minor repairs. In 1864, Norfolk improved to the point that it handled most of the repairs for the North Atlantic Blockading Squadron, but it never regained its pre-war status during the conflict. ${ }^{14}$

12 Canney, Lincoln's Navy, 33-34, 36-38, 41; Paullin, Paullin's History, 295.

13 Craig Symonds, Lincoln and His Admirals (New York: Oxford University Press, 2008), 5152; The Civil War Naval Encyclopedia, ed. Spencer Tucker (Santa Barbara: ABC-CLIO, 2011), 2:482-83, 504. Despite this bungled operation, Captain Hiram Paulding was given command of the Brooklyn Navy Yard in October 1861 and served there with distinction throughout the war.

14 SECNAV Report, 37th Cong., 3rd Sess., 1 December 1862, 569. There was also no budget proposed for the Pensacola Navy Yard which was recaptured by Union troops, but thoroughly destroyed by Confederates. Robert M. Browning Jr., From Cape Charles to Cape Fear: The North Atlantic Blockading Squadron in the Civil War (Tuscaloosa: University of Alabama Press, 1993), 160-61. 
The large and capable Brooklyn Navy Yard, situated among the greatest concentration of civilian shipbuilding and marine service industries in the nation, and access to a substantial labor pool, bore the main burden of transforming the humble U.S. Navy into a force capable of blockading 3,549 miles of coastline. Wars are won or lost through logistics, and that is particularly true for maritime blockade with the requirement to keep fully effective warships on station at all times, in all weathers. That could only be achieved by providing a constant stream of supplies - food and fuel - to the various squadrons, and the regular rotation of vessels on station into port for maintenance and repair, not to mention the inexhaustible demands for human resources: care for sick and injured crew, and the provision of qualified replacement personnel. These were especially daunting challenges in the Civil War because of the vast length of the Confederate coastline, much of it far distant from Federal stations, and the many harbours and river estuaries that had to be closely watched. Most of the Federal naval construction during the conflict had to be contracted to private yards. However, the Union fleet relied on the navy yards and the smaller naval stations for its enormous logistical requirements - that is 11 forms of material and personnel support essential to its operations. Just as New York Harbor was the busiest in the country, accounting for over three-quarters of U.S. imports, the Brooklyn Navy Yard proved to be the busiest home port for the Yankee fleet. $^{15}$

\section{Blockade Operations: Ship Acquisition, Conversion, and Repair}

There was no practical hope of building new warships for the blockade, so the Union Navy Department converted and armed civilian vessels, the age-old method of rapidly augmenting seagoing forces, and the navy yards played a central role in this endeavour. Shortly after Lincoln declared the blockade of southern ports, the Navy Department authorized the yards to acquire and arm vessels and recruit sailors. ${ }^{16}$ Fortunately for the Union, the navy had well established relations with civilian contractors. For instance, in the previous decade the navy had used a civilian contractor to build the engines of the screw frigate Merrimack and her four sister ships. The U.S. enjoyed another advantage with its vast merchant fleet. The decade of the $1850 \mathrm{~s}$ was a golden age for American shipping. In 1858, 76 percent of U.S. exports were shipped in U.S. flagged vessels, and private ship yards were building warships for foreign powers. The sudden cessation of cotton exports left many vessels and sailors out of work and available for government service. By 4 July 1861, barely three months after the war began, eighty-two vessels, carrying 1,100 guns, and crewed by13,000 men had been added to the navy's roster. Most of the warships serving abroad had been recalled and contracts placed with private firms for the construction of twenty-three vessels. ${ }^{17}$

15 Canney, Lincoln's Navy, 42.

16 ORN, I, 5:621-22.

17 Kurt Hackemer, The U.S. Navy and the Origins of the Military-Industrial Complex: 18471883 (Annapolis: Naval Institute Press, 2001), 33-34; Cedric Ridgely-Nevitt, "American Merchant Steamships," Presented at the Annual Meeting of The Society of Naval Architects and Marine Engineers, No. H-14 (New York, 1943), 5-6; Paullin, Paullin's History, 274. 
Two days after the blockade announcement, Welles authorized all navy yard commandants to lease steam ships for a three month duration, but it became quite clear that these old salts were no match for civilian businessmen. Ship owners took advantage of the naval personnel. The vessel Stars and Stripes, worth approximately $\$ 35,000$, was leased indefinitely by the government for $\$ 10,000$ a month. The New York Herald reported condescendingly of the "remarkable patriotism of government contractors" when one ship owner sold two vessels for more than their worth, one of which sank on its first voyage. The Navy Department learned two lessons rather quickly: ships would have to be purchased, and an agent familiar with ship companies would have to be appointed. George D. Morgan, Gideon Welles' brother-in-law, was hired to purchase vessels in New York.

Secretary of the Navy Gideon Welles also established a naval panel to oversee purchasing, and the location of its headquarters in New York indicated that a majority of the fleet acquisition would occur there. The panel's purpose was to standardize government transactions, alleviate the corruption, and perhaps quell the political backlash generated by Welles' appointment of his brother-in-law to a position entrusted with the management of large amounts of public funds. Logic suggested that an area with nearly fifty private ship yards and another six in nearby New Jersey would be a good starting point to build up a fleet. By the end of 1861, the government purchased 133 vessels, and 104 of them were procured in New York. ${ }^{18}$

These ship transactions, while mostly conducted in Manhattan, had enormous implications for the Brooklyn Navy Yard. Of the 671 commissioned vessels that comprised the Union fleet at its greatest wartime strength, only 179 were new construction and most of the rest were civilian vessels that had been purchased and converted. Civilian ship yards handled much of the conversion work. However, the vessels were manned and commissioned at the navy yard. ${ }^{19}$ Most of the newly converted ships had to pass through the Brooklyn Navy Yard.

The preparation of civilian ships for naval service presented a unique set of problems. Ship conversion generally meant reinforcing the decks to support the weight of heavy cannon and designing magazine compartments to store ammunition. Much else, however, was needed to bring civilian vessels up to exacting naval technical specifications. In the fall of 1861, Naval Agent George Morgan complained to Assistant Secretary of the Navy Gustavus Fox that unless the standards were lowered it would be very difficult to raise a fleet. Wartime exceptions would have to be made, and Fox granted a major concession when he authorized the use of iron-bottomed ships, without copper sheathing, the naval standard to reduce fouling of the hull with marine growth. It was not long before ships sailed out of the Brooklyn Navy Yard at a rapid and steady

18 Edward K. Spann, Gotham at War: New York City, 1860-1865 (Wilmington: Scholarly Resources, 2002), 32-33; Symonds, Lincoln and His Admirals, 57; Paullin, Paullin's History, 279-81.

19 ORN, II, 1:27-246; Paul H. Silverstone, Civil War Navies (Annapolis: Naval Institute Press, 2001) is an excellent source for Civil War ship specifications especially for details on acquisition, commission and decommission. 
pace. One ship, Monticello, was converted in less than twenty-four hours. ${ }^{20}$

The Brooklyn Navy Yard was the staging area for one of the earliest and most successful amphibious operations of the war - the capture of Port Royal, South Carolina, on 7 November 1861. Captain Samuel F. DuPont's armada was assembled in New York by mid-October, and consisted of seventy-four vessels and approximately 12,000 men. The capture of this southern port was a great boost to the nation's morale after the debacle at the Battle of First Bull Run the previous summer, and provided the Union with an ancillary depot to support the blockade. ${ }^{21}$ The scale of this operation is a testament to the amount of work being performed on the banks of the East River. The explosive build up of the navy in so short a time period was impressive, but keeping the ships at their posts became an even more daunting task.

Blockade duty required steam vessels, and this presented a multitude of issues. Reliable engines were scarce, as were trained engineers. Ships on station had to have their engines running constantly in order to give chase when a smuggler appeared. The boilers, exposed above deck, were especially volatile; some captains feared boiler explosions more than the enemy. Engineering officers also developed a bad habit of "forcing boilers." When a blockade runner appeared, the firemen would throw grease or tar into the fires to raise steam quickly. The sudden spikes in temperature placed a great strain on the metal boilers often causing them to crack and leak. Lack of spare parts and tools compounded the repair dilemma; as did the elements: winter on the Atlantic coast took a grave toll on machinery. In December 1863, Welles complained that an entire squadron was laid up waiting repairs in the various yards. ${ }^{22}$ The influx of ships into New York for repair was overwhelming. In one year it handled 158 large scale jobs. New York's location in proximity to the squadrons and the availability of skilled labor made it the predominant service station for the fleet. Flag Officer William W. McKean, commanding officer of the USS Niagara, was directed to Boston in early 1862 because the New York Yard was too crowded with ships. With the great diversity in ship types, and the multiplicity of roles in which they were used, many of the repairs and refits were unique. The USS Connecticut had to be refurbished with compartments suitable for ammunition storage when it was ordered to take on a large amount of powder and proceed to the Gulf Blockading Squadron. Many repairs had to be skipped altogether in order to keep the ships on station. In July 1862, Welles directed Captain Hiram Paulding, commandant of the Brooklyn Navy Yard, to perform minimum repairs on vessels from the South Atlantic Blockading Squadron because they were desperately needed on station. DuPont was typical of impatient squadron commanders when he wrote his wife, "I am perfectly indignant at the Department and the New York Navy Yard that neither the

20 Hoogenboom, Gustavus Fox, 100-1; Tucker, Blue and Gray Navies, 31; Craig L. Symonds, "The Economics of Civil War: Money, Manufacturing, and Commerce," in Lincoln and New York, ed. Harold Holzer (New York: New York Historical Society, 2009), 87.

21 Kevin Dougherty, Strangling the Confederacy: Coastal Operations in the American Civil War (Philadelphia: Casemate, 2009), 46-47; Spann, Gotham at War, 34. Spann purports that this was the largest U.S. military landing until the Invasion of Normandy on 6 June 1944. 
Norwich nor Flambeau are yet repaired. The surveying officers at New York said it would take three weeks...." A year later Welles again directed Paulding to skip repairs altogether so that men could be shipped to Rear Admiral John A. Dahlgren. ${ }^{23}$ Such urgency indicates that the yard was working at or over capacity.

By early 1862, the blockade had been divided into four squadrons: the North and South Atlantic Blockading Squadrons and the East and West Gulf Blockading Squadrons. One would think that the Brooklyn Navy Yard handled most of the North Atlantic Blockading Squadron's repairs since it was the closest. In fact the North Atlantic squadron's repairs were generally handled by the smaller auxiliary stations between Wilmington and Philadelphia, and New York was more engaged with the lower three, especially the farthest Gulf Squadrons. In December 1861, Welles authorized Flag Officer McKean to send his ships operating in the Gulf of Mexico north for repairs; the Navy Department knew full well that facilities in the Gulf were inadequate. During the summer of 1862, DuPont sent four of his most important ships, USS Unadilla, Ottawa, Seneca, and Pembina, the core of his fleet, to New York for repairs, accompanied by a personal note to give them priority. Paulding authorized night work at the yard to expedite their return. Rear Admiral David Farragut even sent a damaged anchor from his flag ship USS Hartford to Brooklyn, explicitly stating that it could not be fixed in

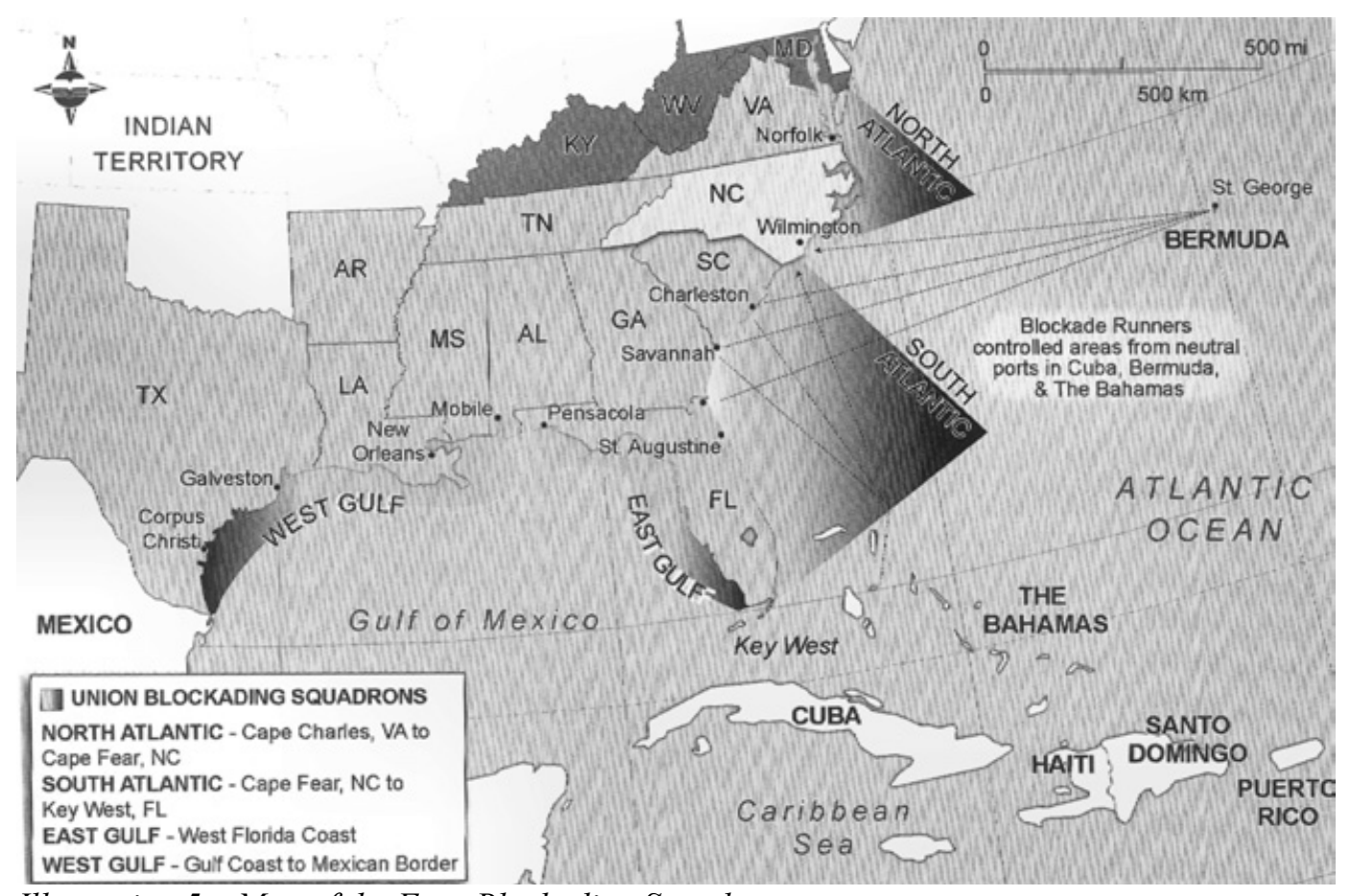

Illustration 5 - Map of the Four Blockading Squadrons

23 Canney, Lincoln's Navy, 44; Paullin, Paullin's History, 293; ORN, I, 17:56-57; ORN, I, 27:397; ORN, I, 13:200; ORN, I, 27:258; J.D. Hayes, ed.; Samuel Francis DuPont: A Selection From His Civil War Letters (New York: Cornell University Press, 1969), 2:198. 
Pensacola. ${ }^{24}$ No doubt, repairs took priority at the navy yard, but the fleet had to be armed and supplied as well.

\section{Logistics: Supplies, Men, Medicine, and the Russians}

With war raging on the Mississippi River, the nation's north-south trade was disrupted and most of the Union's goods flowed east. The Brooklyn Navy Yard's large warehouses were quickly inundated. Even before the war broke out, Commodore Horatio Bridge, chief of the Bureau of Provisions and Clothing, acknowledged that the main depot for the fleet was located in Brooklyn. He requested that a new hoisting apparatus be built as well as a railway to the waterfront to streamline the loading and unloading of vessels. Reports from the chief of the Bureau of Yards and Docks requested larger storage units and more land throughout the war. The construction of a chain cable shop was proposed in the hopes of making the yard more efficient. Chain and anchor production usually occurred at the Washington Navy Yard, but since so many ships were outfitted in New York, it made sense economically to avoid the transport between yards. ${ }^{25}$

Because the Brooklyn Navy Yard was the fleet's premier supply repository, early attempts to supply the blockaders via a seaborne route began there. The steamer Rhode Island sailed out of New York in July 1861; it was the first attempt to seaborne supply for the blockading squadrons. Soon refrigerated steamers loaded with beef and fresh vegetables were making regular trips along the coast. Correspondence between the Navy Department and the naval storekeeper in New York recorded squadron commanders pleading for supplies. Commandant Paulding spent a great deal of time in late 1862 through 1863 ordering supply ships to the South Atlantic Blockading Squadron and the Gulf. Although the Brooklyn Navy Yard did not manufacture naval ordnance, it was a significant depot. The gun park there had a 2,000 gun capacity. ${ }^{26}$

Manning the fleet was another constant and pressing concern for the Navy Department, and here again they looked to New York. Fox complained to Farragut that "unless we can ship contrabands and rebels we shall be ashore about men. There are but 49 seamen available at all ports." 27 ("Contraband," that is former slaves, did serve aboard many U.S. ships.) Recruiting rendezvous were set up all along the east coast, and only Boston could rival New York with regard to enlistments, further exacerbating the workload of the yard. The receiving ship North Carolina was a permanent fixture on Wallabout Bay. The old 74-gunner could berth 1,000 men. Onboard, recruits received uniforms and rudimentary seamanship training, and waited for orders. It also served as a brig. In 1864, the New York Volunteer Committee (Draft Board), weary from the previous year's riots and attempting to fill the city's quotas, raised the bounties for naval recruits. Brooklyn was overwhelmed with nearly 5,000 enlistees. Furthermore, the board

24 ORN, I, 17:10; ORN, I, 13:285-86; ORN, I, 21:675-76.

25 SECNAV Report, 36th Cong., 2nd Sess., December 1, 1860, 347; SECNAV Report, 37th Cong., 3rd Sess., 1 December 1862, 563-64.

26 Paullin, Paullin's History, 289, 291-92, 313; ORN, I, 13:462, 472, 710; ORN, I, 27: 509.

27 ORN, I, 21:750-51. 
was authorized to count all naval recruits from the beginning of the war towards their quota. The final tally of 19,477 seamen was a considerable contribution. ${ }^{28}$

Sanitation was essential for the well being of men living together in tight quarters aboard ships, and even before the war broke out the navy was committed to improving health conditions. The U.S. Navy operated eight hospitals at the start of the war. The Naval Marine Hospital, on the grounds of the Brooklyn Navy Yard, was established in 1833. A laboratory was established twenty years later to improve and standardize shipboard medicine. Edward R. Squibb worked here as a navy doctor for twelve years before opening his own pharmaceutical company at nearby Furman Street in 1858. Physicians at the yard laboratory produced most, if not all, of the navy's pharmaceuticals. The large medical facility at Norfolk was commandeered by the U.S. Army so Brooklyn attended to a majority of the naval casualties during the conflict. ${ }^{29}$ It should not be surprising that most of the wounded were sent to New York. The constant flow of ships from the blockade stations into Brooklyn made the naval hospital there a logical drop off point.

Officers and staff of the Brooklyn Navy Yard were called upon for many miscellaneous duties. In September 1863, for example, a Russian squadron unexpectedly sailed into New York Harbor. Fearing the outbreak of a general war in Europe, the Russians sought a safe, iceless harbor to winter while affairs abroad unfolded. Commandant Paulding was directed to offer the services of the yard to the Russian guests. A more typical experience was the adjudication of war prizes. The U.S. Navy captured over 1,100 vessels during the war, many of which were cleared through New York Prize Courts and sent to Brooklyn. Throughout the war, unscrupulous merchants carried on an illegal trade with the Confederacy, usually through the Bahamas or Matamoros, Mexico. So serious was the problem that that Paulding stationed the USS Vicksburg off Staten Island and the USS Peterhoff off Throggsneck to examine all outbound ships, and seize any vessel that did not have proper documentation. Aid to the civil power also made demands on the yard. At the end of June 1863, Major General John E. Wool, commanding the defenses of New York, and Mayor George Opdyke urged Paulding to delay the departure of the USS Roanoke because the city's military garrison was depleted by the emergency transfer of regiments to Pennsylvania to defend against the Confederate offensive into that state. In the following month, the yard dispatched gunboats to Manhattan to help suppress riots against the military draft. ${ }^{30}$

28 Dennis J. Ringle, Life in Mr. Lincoln's Navy (Annapolis: Naval Institute Press, 1998), 26-27; Browning, From Cape Charles to Cape Fear, 201; Paullin, Paullin's History, 289, 291-92; Spann, Gotham at War, 180.

29 Ringle, Life in Mr. Lincoln's Navy, 108-9; Paullin, Paullin's History, 292-93; Browning, Cape Charles to Cape Fear, 208; E.A. Livingston, President Lincoln's Third Largest City: Brooklyn and the Civil War (New York: Budd Press, 1994), 92-93.

30 F.A. Golder, "The Russian Fleet and the Civil War," American Historical Review 20 (1915):803, 807-8; Paullin, Paullin's History, 279-80; O.R.N., I, 2:574, 577, 582; O.R.N., I, 7:348; U.S. Navy Department, Civil War Naval Chronology, sec.3:114; U.S. Congress, Report of the Secretary of the Navy in Relation to Armored Vessels (Washington D.C.: GPO, 1864), 604. 


\section{Demobilization/Conclusion}

At the end of the war, the Navy Department wanted to demobilize the fleet just as quickly as it had been assembled. The port where most of the civilian vessels had been purchased would be the same place where many of them were sold: New York. In the spring of 1865, auctions and ship decommissions soon took precedence over repair and outfitting. By June, the entrance to Wallabout Bay was clogged with ships waiting to be sold. The post-war navy clerk's log Brooklyn is filled with entries about the selling off of vessels: ten on 25 August 1865, for example, and another 27 on 21 September 1865. In all, 122vessels were decommissioned at the Brooklyn Navy Yard. DuPont sent all his surplus ordnance to the New York gun park. By May 1868, the U.S. Navy had relinquished 429 vessels and maintained a fleet of eighty-one commissioned ships. ${ }^{31}$

At its peak in 1864, the Brooklyn Navy Yard employed nearly 6,000 people, a striking increase from a decade earlier when a typical large ship yard had about 400 workers, and an indication of the scale of operations carried out at the yard. Six hundred were laid off within a month after the Confederate surrender at Appomattox Courthouse, and another 2,000 by the end of the year. ${ }^{32}$ The rapidity of the demobilization also indicates the extent to which Brooklyn had been committed to support of the blockade. With the ending of the blockade at the cessation of hostilities, there was no longer any need for the many converted civilian vessels that had carried the brunt of the work, or for service ashore that had sustained the watch on Confederate shores. In assessing the Brooklyn yard's place in the wartime naval effort, the proposed budgets from the Annual Reports of the Secretary of the Navy is telling. New York was consistently given priority and substantial fiscal allocations throughout the conflict (see Figure 6). The only facility that came close to New York's budget was Mare Island, San Francisco. This was a fairly new yard and the only facility on the west coast. The Navy Department, taking a global strategic view of American interests in the Pacific, was very concerned with getting Mare Island fully operational. Boston's budget was an anomaly in 1865 when a large tract of land was purchased to expand the facility. In his final wartime report, the chief of Bureau and Docks stated "At the New York Yard, where the heaviest and largest portion of naval work is done, the working ground is so much crowded that it is with difficulty that the various operations of the yard can be carried on to advantage.",33

Throughout the Civil War, the Brooklyn Navy Yard was indispensible to the Union naval blockade. Many factors contributed to this. First and foremost was its location in one of the busiest ports in the world. It was relatively safe from attack, despite constant fears of sabotage, and surrounded by a thriving maritime industry. New York, after the destruction of Norfolk, was also the major yard best placed to support of the the blockade squadrons. A majority of the blockaders were acquired and

31 John Niven, Gideon Welles: Lincoln's Secretary of the Navy (New York: Oxford, 1973), 507; Paullin, Paullin's History, 313; ORN, I, 13:320; New York Navy Yard Clerk's Log, RG 181, Series 252, NARA - New York, 8, 5, 46, 59.

32 Spann, Gotham at War, 188; Thiesen, Industrializing American Shipbuilding, 61.

33 SECNAV Report, 38th Cong., 2nd Sess., 5 December 1864, 754. 


\begin{tabular}{|l|l|l|l|l|l|}
\hline & 1861 & 1862 & 1863 & 1864 & 1865 \\
\hline Portsmouth, New Hampshire & $\$ 82,260$ & $\$ 132,632$ & $\$ 132,432$ & $\$ 316,250$ & $\$ 505,988$ \\
\hline Boston, Massachussetts & $\$ 170,500$ & $\$ 278,566$ & $\$ 184,500$ & $\$ 493,500$ & $\$ 1,883,753$ \\
\hline Brooklyn, New York & $\$ 231,815$ & $\$ 463,003$ & $\$ 979,315$ & $\$ 1,065,663$ & $\$ 2,597,080$ \\
\hline Philadelphia, Pennsylvania & $\$ 72,515$ & $\$ 230,458$ & $\$ 384,945$ & $\$ 285,680$ & $\$ 349,508$ \\
\hline Washington D.C. & $\$ 68,155$ & $\$ 131,871$ & $\$ 229,465$ & $\$ 218,300$ & $\$ 254,690$ \\
\hline Mare Island, California & $\$ 431,376$ & $\$ 366,363$ & $\$ 374,735$ & $\$ 348,800$ & $\$ 484,800$ \\
\hline Norfolk, Virginia & $\$ 223,066$ & $\$ 0$ & $\$ 73,433$ & $\$ 544,000$ & $\$ 484,500$ \\
\hline Pensacola, Florida & $\$ 283,500$ & $\$ 0$ & $\$ 50,000$ & $\$ 171,000$ & $\$ 422,887$ \\
\hline
\end{tabular}

Table 1 -- Annual Proposed Budgets for the Eight Federal Navy Yards.

commissioned at the Brooklyn yard, and its docks were constantly jammed with ships waiting for service. Supply steamers made regular stops at New York to procure food, clothing, and ordnance. The medicine lab at the Marine Naval Hospital supplied most of the medicine for the blockaders, and most of the sick or injured personnel were treated at the hospital. Many a sailor entered the navy at the receiving ship North Carolina, and once hostilities ceased the yard became one of the main centres for demobilization.

The blockade was a major component of the Union war effort, accounting for one twelfth of total war expenditures. The effectiveness of the blockade has been much debated, but recent scholarship has suggested its impact was fundamental to the depletion of Confederate resources. Certainly the blockade was central to the collapse of the cotton trade, the principal Confederate export, whose loss the fledgling nation's economy could not long endure. ${ }^{34}$ The key to the blockade was the meteoric buildup of the Union Navy was meteoric, and of the logistics system that sustained the squadrons on station. The Brooklyn Navy Yard was central to both achievements - it truly was the heart of the Union anaconda.

34 David G. Surdam, Northern Naval Superiority and the Economics of the American Civil War (Columbia, University of South Carolina Press, 2001), 206-7. 
